\title{
PRODUCTIVITY, AS AN INDICATOR OF THE EFFICIENCY OF A COUNTRY'S ECONOMIC SYSTEM: A LATVIAN CASE
}

\section{Gunārs Vaskis}

Dr. oec.

\section{Egils Fortiṇš}

M. commerc., M. oec.

\begin{abstract}
The aim of the article is to show the range of issues to consider when developing a country's economic policy for increasing productivity.

The relative level of national development over a period of time, on the one hand, is the goal of prosperity for any country and its inhabitants. On the other hand, in an open society, in the larger economic space (EU) of the free movement of people (including goods, capital, etc.), this is a condition for sustainable development. The relative level of socio-economic development of the country, without going into detailed relationships, is characterised by GDP per capita. From a production point of view, the labour force in the productive sectors, whose efficiency is reflected in labour productivity, generates the gross mass of GDP.

When deciding on the formulation and implementation of national economic policies, governments face a very significant problem: the assessment of productivity and its interaction with other factors. This is especially important for small countries, such as Latvia. This is not possible if the economic category itself - productivity is not defined with sufficient precision. Productivity is a multi-dimensional concept, which has become one of the basic principles upon which modern economic thinking is based. The concept of productivity includes not only economic factors, but also noneconomic factors such as education, science, political stability and value systems. By creating conditions for productivity increase, a dynamic and systematic approach to creating wealth and long-term economic growth is necessary.
\end{abstract}

Keywords: Latvia, labour productivity, competitiveness, economic policy

\section{Introduction}

There are many studies in the world of economics that give a fairly clear answer to both the nature of productivity, the importance of factors, the level determining factors, and the toolbox for increasing this level. The question remains as to why, in the European post-socialist countries, almost 
30 years after the dismantling of the socialist system and its planetary economy, the productivity level shows a critically low level compared to the EU-15. Moreover, even in Latvia, where the level of productivity is critically low, so far there have not been enough studies that could serve as the basis for political decisions. The current situation shows that labour productivity in Latvia is catastrophically low. According to EUROSTAT data, in 2015 labour productivity (as to the value added per employee) in Latvia was 16.7 ths. EUR per year, which was $38 \%$ of the EU28 average and $20 \%$ of the EU28's best (Denmark). Compared to Estonia, this indicator in Latvia was only $65 \%$ of Estonia's reported productivity. A lower productivity level was reported only in Bulgaria and Romania.

Figure 1. Apparent labour productivity (Gross value added per person employed) - thousand euro, 2015



Source: Eurostat database, Author's calculations

The current situation shows:

- profound problems in the Latvian economy,

- the inability of the free market to solve inefficient national economic problems, and

- the need for state intervention in solving the problem. 


\section{Nature of Productivity}

Productivity is used to evaluate the efficiency of the use of factors by comparing the volume produced with the quantity of factor used. Labour productivity, which is the most common indicator of productivity measurement, is the amount of output corresponding to the labourintensive acquisition or defined as the value added per hour worked [9]. Work productivity is determined by human capital, technological change and economies of scale [15].

Capital productivity is defined as gross output or added value. Capital productivity improves the quality of work thanks to the improvement of machinery and equipment. It is essential to understand the difference between capital productivity and the rate of return on capital. Capital productivity is a physical productivity indicator, but a capital return rate is an income indicator that indexes capital gains from equity capital [12].

One of the topical concepts is the concept of a total factor productivity (TFP) [14]. The overall factor productivity is important not at the company level, but also at the national level, as it enables the development of a balanced state economic policy. The productivity of total factors can be calculated by dividing the total output by the total investment. The growth of the TFP also reflects the so-called impact or the external impact of the return on investment that goes beyond those that the investor can internalise. The consequences of this overcoming are mainly due to the social benefits resulting from technological advances and innovation.

\section{Measurement of Productivity}

Measurement of productivity in many cases relates to the availability of data. Generally, productivity can be measured as the productivity of one factor (referring to the output indicator for one investment indicator). Productivity can be measured as multi-factor productivity (which refers to the output measurement set of inputs). Another difference that is particularly significant at the industry or enterprise level is the productivity measures that cover some of the gross output volumes for one or more raw materials and those who use the concept of value added to capture the product movement. $[9,12]$

The OECD has developed several measurement methods for measuring various types of productivity see Fig. 2.

This article will focus on productivity gains and will be based on the Eurostat definition of labour productivity.

"Apparent labour productivity is defined as value added at factor costs divided by the number of persons employed. This ratio is generally presented in thousands of euros per person employed". [5] 
Figure 2. Overview of main productivity measures

\begin{tabular}{|c|c|c|c|c|}
\hline \multirow[b]{2}{*}{$\begin{array}{c}\text { Type of } \\
\text { output } \\
\text { measure }\end{array}$} & \multicolumn{4}{|c|}{ Type of input measure } \\
\hline & Labour & Capital & $\begin{array}{l}\text { Capital and } \\
\text { labour }\end{array}$ & $\begin{array}{l}\text { Capital, labour } \\
\text { and intermediate } \\
\text { inputs (energy, } \\
\text { materials, services) }\end{array}$ \\
\hline $\begin{array}{l}\text { Gross } \\
\text { output }\end{array}$ & $\begin{array}{l}\text { Labour } \\
\text { productivity } \\
\text { (based on } \\
\text { gross output }\end{array}$ & $\begin{array}{c}\text { Capital } \\
\text { productivity } \\
\text { (based on gross } \\
\text { output) }\end{array}$ & $\begin{array}{l}\text { Capital-labour } \\
\text { MFP (based on } \\
\text { gross output) }\end{array}$ & $\begin{array}{l}\text { KLEMS } \\
\text { multifactor } \\
\text { productivity }\end{array}$ \\
\hline \multirow[t]{2}{*}{$\begin{array}{l}\text { Value } \\
\text { added }\end{array}$} & $\begin{array}{l}\text { Labour } \\
\text { productivity } \\
\text { (based on } \\
\text { value added }\end{array}$ & $\begin{array}{c}\text { Capital } \\
\text { productivity } \\
\text { (based on value } \\
\text { added }\end{array}$ & $\begin{array}{l}\text { Capital-labour } \\
\text { MFP (based on } \\
\text { value added }\end{array}$ & - \\
\hline & \multicolumn{2}{|c|}{ Single factor productivity measures } & \multicolumn{2}{|c|}{$\begin{array}{c}\text { Multifactor productivity (MFP) } \\
\text { measures }\end{array}$} \\
\hline
\end{tabular}

Source: OECD manual $[11,13]$

In turn, Eurostat's productivity definition is based on the definition developed by the OECD; "Apparent labour productivity is defined as value added per person employed". [12, 32]

$\frac{\text { Quantity index of value addied }}{\text { Quantity index of labour input }}$

Both firm management and the government are embedded in the most rational use of jobs to create added value. The productivity of the work only partially reflects the productivity of the employee's personal capacity or the intensity of their use. The relationship between output and labour input depends to a large extent on the use of other resources.

When comparing productivity measurement based on gross output, measured by productivity based on added value, it should be noted that the growth rate of value-based productivity is less dependent on any variable intermediate between labour and labour or the degree of vertical integration. Value-added productivity measures tend to be less sensitive to material and service and labour substitution processes, rather than measures based on gross output. For example, when using outsourcing, the workforce is replaced by intermediate inputs. This leads to a decrease in value added as well as a decrease in labour costs. The first effect increases the measured productivity; the second effect reduces it.

As labour productivity measures reflect the combined effects of capital investment, intermediate investment and total productivity changes, 
they do not exclude any direct technical change effects, whether they are embedded or dispersed. The latter works with capital goods and intermediates and thus affects labour productivity; the former usually increases production opportunities for a given set of raw materials, and it also affects productivity.

At the aggregate level, value-based labour productivity forms a direct link to the widely used standard of living, per capita income. Productivity has a direct impact on living standards by adjusting variable working hours, unemployment, labour force participation rates and demographic changes.

From a policy point of view, value-based labour productivity is important as an argument in the negotiations on the salary of a job.

The current paradigm ${ }^{1}$ : to increase national growth, wages, etc. it is necessary to increase productivity. However, productivity cannot be increased - it is a result, it may be a goal, but not a means (even for GDP or welfare enhancement).

Labour productivity is an indicator of the efficiency of work, which personifies the collective nature of work in the indicator of the efficiency of individual companies, which is an indicator of production efficiency at an enterprise level.

The total industry or economic productivity indicator is an aggregate, which depends on the labour productivity of individual companies and the parameters of the industry or economic structure. At any aggregate level of the economy, labour productivity is an indicator of the efficiency of this system.

\section{Productivity and Value Chains}

Productivity at enterprise level shows the efficiency of the management system in the environmental constraints of the environment. It should be borne in mind that the corporate governance process is not limited to the process of converting input products. The company's efficiency is determined by a set of value chains that includes $[20,14]$ :

1. New product development;

2. R\&D, design;

3. Key parts and components;

4. Base material;

5. Assembly/ labour intensive service;

6. Distribution;

1 Paradigm (gr. П $\alpha \rho \alpha ́ \delta \varepsilon \iota \gamma \mu \alpha$ "model, image, sample") - a certain pattern of perception and thinking, a world view, the main theoretical assumptions (framework). Encyclopaedic Dictionary of History. http://vesture.eu/index.php/Paradigma 
7. Retail / after sale service;

8. Marketing / branding; and

9. Supply chain management.

Consequently, productivity is not only a direct result of the production process, but also the result of the whole chain of value chain creation.

Taking into account the size and structure of the Latvian economy, the level of production concentration, optimal sizes of export-capable enterprises, etc.; particularly important is the involvement of Latvian enterprises in the global value chain (GVC).

Participation in GVCs through exports boosts productivity and allows Latvian firms to increase better quality jobs, yet only the most productive firms are able to participate in GVCs. Further integration in GVCs may result in a wider productivity gap between a handful of exporters and the large mass of non-exporters, unless the number of firms participating in GVCs increases. A more inclusive participation in GVCs requires boosting the productivity of smaller non-exporting firms and ensuring that firms seeking to start exporting can access the resources needed to overcome barriers to enter export markets. [20,19]

The discussion of productivity in the public space, taking into account the denominator of the productivity formula, tends to focus on a low level of labour force that is reasonably related to labour education and motivation. However, such an opinion can be considered superficial, and usually expressed by non-specialists.

\section{Productivity and the Technical Level of Production}

The primary level of productivity is determined by the technical level of production, which in most of the company are equipment and machinery. Any company does not have significant (systemic) restrictions on the purchase of technically high-quality equipment and machinery. Consequently, in Latvia there are no constraints on the technical factor for ensuring the level of productivity of developed countries. Problems may arise in the area of financing purchases of equipment, but this relates to demographic characteristics, size, capital adequacy, reputation and other factors limiting funding. The conditional productivity level of technical systems can reduce the level of capacity utilisation, which is basically dependent on the company's management factors (organisation, marketing and sales, etc.).

In assessing the productivity of a company's technical systems, which is estimated by natural indicators, it should be taken into account that the economic operator can offset the technical level of lower equipment, 
by minimising other costs. The purchase of equipment from an economic point of view is determined by the results of Cost Benefit Analysis. As a result, low labour costs can be a reason for the use of low-output technical systems.

Given that the value added is based on the product's market price, the value added in the price depends on the cost of the intermediate product. Under international competition conditions, it can be assumed at large that the cost of an intermediate product in a particular company is consistent with the average cost of the intermediate product market for the product in question, or is negligible. Of course, there are some differences in costs. For example, in the case of Latvia, electricity prices are disproportionately high, as they include mandatory payments, which, by their very nature, are taxes. It should be borne in mind that the cost of an intermediate product depends not only on its market prices, but also on the normalisation of the use of an intermediate product, which is an element of the production organisation and depends on the management of the company.

In this case, the amount of PV generated by one employee depends on the amount of output generated, irrespective of the cost of the intermediate product. Abstracted from the differences in the labour productivity of the product, the value-added structure is basically determined by the level of capacity utilisation. The capacity utilisation decreases from the optimal level, the proportion of fixed costs (in the form of depreciation of fixed assets) increases in the price of the whole product or production unit and, consequently, in value added. The above relations, on the basis of an abstract example, are illustrated in Figure 3.

Figure 3. Value-added structure in the product, depending on the cost of the intermediate and capacity utilization (abstract example)

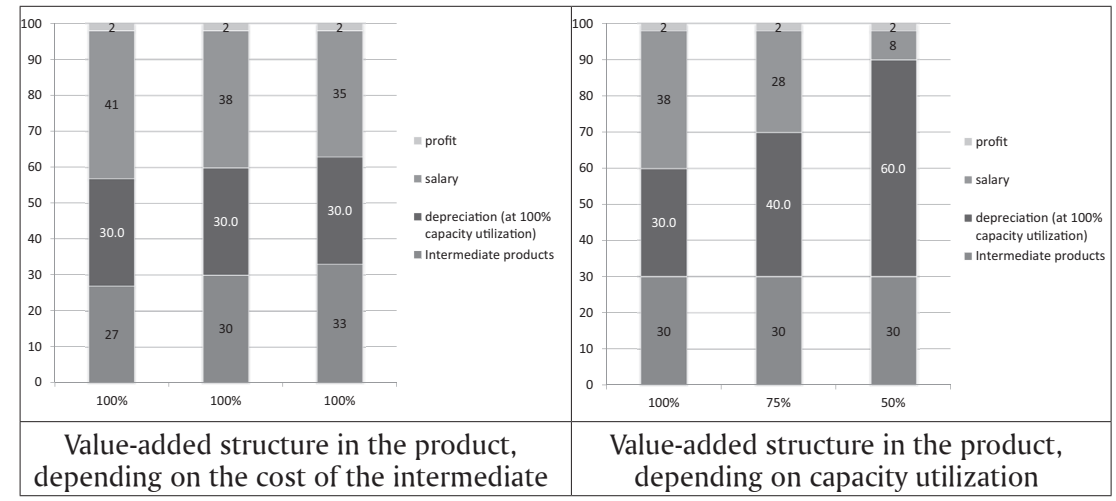

Source: Author's calculations 
In the example, the assumption is that a merchant uses a constant margin $(2 \%)$ in each option. Statistical data and research results show that entrepreneurs in Latvia use higher profit margins than in Europe, which leads not only to low wage levels, but also to a decrease in the level of competition. Relatively high Latvian price-cost margins suggest less intense competitive pressures than in other European Union (EU) countries [19, 10].

The efficiency of using fixed assets (especially technological equipment) is one of the main factors of productivity. At the same time, it determines wages and salary levels. One cannot conceive of the rationale that wage growth cannot yield productivity gains. At the same level of productivity, the wage level depends on the level of utilisation of the power and the distribution of value added by the entrepreneur.

The division of value added at the level of entrepreneurs in Latvia leads to short-term consumer interests over the long-term development needs of the company, and undervaluation of labour costs.

\section{Productivity and Workforce}

In the public space, speaking about the low level of wages, a low level of labour productivity is put forward in Latvia as an argument. Further arguments are put forward in the case of low qualifications of labour force, low motivation and low ethical work. However, this approach is too simplistic and does not provide answers to critical system issues, for example:

1. The unanswered question remains why a Latvian construction worker in the United Kingdom has several times higher productivity than in Latvia, or the Latvian policeman, doctor, fire-fighter has lower work intensity and professional abilities, than in Germany, France or Sweden.

2. Does the German truck driver drive more than a tonne/kilometre as a Latvian driver, etc.?

The labour force is the one required by the technical level of production. Adapting the labour force to technical system changes is less time-consuming than the development cycle of the relevant technical systems. Labour force potential is characterised by qualification. The actual labour force's efficiency, along with qualifications, is determined by the organisation of production and the motivation of the staff.

Labour force qualifications are formed within the framework of general and vocational education systems, which is based on the state function. However, based on the system approach, it can be safely asserted that this is not just a matter of education.

1. The ability of generic and vocational education systems to prepare well-educated workforce is inextricably linked to educational 
motivation. Each individual decides to deliberately or unknowingly make choices within the CBA. Taking into account the low potential of a potential workforce to predict or predict the future, decisions are made on the basis of the assessment of the current or past circumstances.

2. Thus, it is precisely the function of the state that is not only to create an education system compatible with the time cycle of education and vocation acquisition and the parallel scientific and technological development process, but also to create the right landmarks for the individual selection process.

3. It should be taken into account that orienteering is not only the creation of educational places suitable for the future structure of the economy and the propagation of the professions concerned. The CBA includes a cost-benefit assessment. The predicted relative standard of living is one of the most important parameters in the decision-making process for choosing a profession.

4. It is not possible to analyse in detail the problems of the current system of academic and vocational education systems and the ways of piloting in the scope of this publication, but it is worth pointing out that the system of vocational education is not limited to the acquisition of the first state occupation, but should be included in the conditions of a rapidly changing labour market demand, recurrent vocational training (lifelong learning).

5. It should be taken into account that recently vocational education has been limited to a state-organised system. Equally important is the acquisition of professions in the company. It involves, as with the full acquisition of the profession, the development of basic vocational education skills in accordance with the specifics of the company, retraining for work on the new technique. However, it should be taken into account that such professional training is primarily possible in medium and large enterprises.

6. The structure of the size of companies is one of the problem areas for the professional development of individuals with higher education. In the current situation, a large part of the company (and can be found by job advertisements) is looking for experienced staff. Experience can be obtained only during the work process, but often the duration of the experience does not determine its quality.

7. In today's highly technological production conditions, the total productivity level in the economy depends on a number of factors of the national economy, including sectorial structures of the economy, $R$ \& D intensity, production concentration level, distances of the main export market, etc. A number of factors mentioned above inevitably relate to the size of the state. 


\section{Specificity of Economic Growth of Small Countries}

A country's economic policy depends on the size of the country. This is because the ability of the state to implement one measure or another depends on the size of the state. Economics does not have a uniform approach to national classification.

"Small States" as by the Commonwealth Secretariat is a group of sovereign countries with a population of 1.5 million people or less, plus a number of larger countries (Botswana, Jamaica, Lesotho, Namibia and Papua New Guinea) that share certain characteristics [19, 101].

In the Paper "Small states in a global economy: The role of institutions in managing vulnerability and opportunity in small developing countries" authors discuss the definitions of "small countries" given in the literature. "There is little agreement over what actually constitutes a 'small' country. Recent research by Easterly and Kraay (2000: 2014) on 'microstates' includes those 'having an average population over the period 1960-1995 of less than one million'.

Others have used population figures of one and a half million (Commonwealth Secretariat, 2000); three million (Armstrong \& Read, 1998); five million (Collier \& Dollar, 1999), and ten million (Kuznets, 1960; Streeten, 1993). The authors use the figure of five million (1998 population) as the cut-off, since this is approximately the median population of all countries in the world" [3, 7-8].

Despite the size classification of different countries, Latvia is clearly in the same category as a small country.

Most author's small national problems relate to the following factors:

- Small Domestic market;

- Large Openness to Foreign Trade;

- Small Domestic Market;

- Limited Resources.

The authors of this study, on the basis of literature analysis, outline the main problems of small economies: "Due to its small population size, a small state distinguishes itself by its limited labour force... Small countries possess a smaller range of special skilled labour compared with their large counterparts [... Potential staff shortages, which may occur during the restructuration process of production if only a limited number of special skilled workers are available among the existing labour units. Specialisation in labour-intensive products is harder in countries with a small population. If a state is restricted by a small (territorial) area, there is often a scarcity in natural resources, which may affect the diversification possibilities in production and exports. When a country possesses vast territories, but has a low population, it is unlikely that there would be enough capital available to exploit the natural resources. The government would then 
need to attract enough foreign capital (i.e. in the form of foreign direct investments) to balance its low domestic capital reserves. Foreign countries would be hesitant to invest in such small states, since it is assumed that there are limited market opportunities due to low domestic demand. A further negative effect can be caused by the brain drain, which occurs when there is a lack of investment in the domestic high-skilled sectors (such as research and development). A small domestic market and demand limit the production of positive (internal and external) economies of scale, usually accomplished by large companies and industries... Producers in these countries are confronted with relatively high unit prices, which may raise the final sales price. The low number of firms in the industry also limits competition and the efficient allocation of resources. Monopolies and oligopolies may arise in this case, which would further hinder innovation. Small countries tend to have high levels of government consumption, since certain specific government expenditures occur in both small and large states. However, there are fewer taxpayers in small countries to bear the burden of financing government expenditures. Relatively high level of spending in the public sector is often countered by economies of scope. Public employees in these countries must often perform multiple tasks in order to reduce personnel costs. This may be related to a loss of quality of the public goods provided by a small state" [7].

The problems of Latvia as a small country are reflected in the small population, which continues to decrease as a result of economic factors. The decrease in the number of inhabitants inevitably leads to a decrease in the density of population, which increases the cost of maintenance of the national economy and social infrastructure per employee. Despite the fact that there are seven large (republic) cities in Latvia, only the population of Riga and its prospective assessment let one hope for serious foreign investments in the real sector of the economy.

\section{The role of the state in increasing productivity}

Productivity is determined by the availability of resources, their quality and their efficiency. At the enterprise level, this means effective management of the company. The company operates in an environment created by the market and the state. Consequently, it is necessary to define the role and place of the state in increasing productivity.

\section{Economics as a System}

The economy is a system. It can be recognised by default or by public declaration. If this is a system then one needs to use system access. 
Without going into the definitions of the systems, from the point of view of system theory, the economy can be defined as an open self-organising system. This leads to two important aspects.

First, the economy is a managed system, therefore, for the functioning of the economy and the provision of homeostasis, (".. the characteristic of the system to maintain the essential parameters of the boundary of the system in the system's interaction with the environment ..), the essential characteristics are closely related to the basic quality of the system, the disruption of which leads to the destruction of the system $[10,80])$ and requires management.

The economy has full control over the elements of the management system and the functions and functioning of the principles. Consequently, the first parameter of the management system is the determination of the target. It should be borne in mind that a macro-system can also participate in setting targets for each specific level of management (for example, the common objectives of the EU in the framework of the individual Member States' objectives).

The overall goals of the economy, as is the case with the international consensus, are full employment, price stability, balance of payments balance and sustained and comparable growth $[2,80]$.

Two of these are related to work - growth and full employment. Moreover, both of these indicators are interdependent.

An essential issue is the relationship between economic growth and development. A simplified view allows one to assume that both of these categories are in parallel. However, both these synthetic indicators are in mutual interaction. Within the framework of the economic management system, it is necessary to optimise the content indicators of both of these categories and the factors of interaction. For example, there can be economic growth, but if all the money goes in depreciation and the profit of the entrepreneur, there is no development, (there is no money for education, infrastructure, health, purchasing power of people).

Management is a function of the system that is focused on preserving the main parameters (the loss of which parameters lead to a system collapse when the environment changes), or the management is oriented to the execution of a specific program that provides stable functioning, homeostasis, to achieve certain goals [9, 592].

At the macro-economic level, the management entity is the government (or its specialised management substructure). Consequently, economic governance is a function of government. Effectiveness of the functioning of the economic system is an indicator of the efficiency of government functioning. 
The private and public sectors are closely intertwined in modern economies. They interact with each other with each other $[2,65]$.

The state and economy are related as follows:

1. A country with income redistribution ensures the satisfaction of collective needs (education, health, social security, safety);

2. The state must create the appropriate legal order for the desired economic order;

3. The functioning of the market depends on circumstances, which the market itself has not created; and

4. Business shall be established in cases where the private sector does not do this for certain reasons or it is risky to transfer certain types of economic activity to private hands $[2,75]$.

According to OECD estimates a gradual alignment of product market regulations to best practices in a broad range on non-manufacturing sectors could boost aggregate labour productivity levels - and thereby potential GDP -by several per cent over a decade (Bouis \& Duval, 2011) [19, 10-11].

\section{Public Administration and Labour Productivity}

Primarily the institutions and government policies that make up the economic environment within which individuals determine a country's long-run economic performance and firms make investments, create and transfer ideas, and produce goods and services $[18,114]$.

$\mathrm{MGI}^{2}$ productivity studies point out "The role of government in helping boost productivity is likely to be even more significant in developing economies than in developed ones. The author's analysis suggests that about 60 percent of productivity growth in agriculture, 40 percent in the automotive sector, and 35 percent in retail will be tied to policy change in developing economies. The policy barrier is lower in developed economies, but even here, one still sees around 25 percent of the opportunity in agriculture and 10 percent of the retail opportunity being dependent on policy changes. These findings are in line with previous MGI research that has indented policy as a critical barrier to (or critical enabler of) productivity growth, accounting for over half of the productivity gap between Brazil, India, Japan, and South Korea and the productivity frontier. Overcoming policy barriers will require a clear understanding of the role that government policy and actions have on productivity, employment, and other goals in the specific context of each country. The most effective role of government also depends on the characteristics of the sector, including

2 The McKinsey Global Institute. 
exposure to global competition, capital intensity, speed of innovation, and industry structure. One-size- fits-all solutions are rare. Instead, governments need to tailor their interventions and approaches to the sector. Ultimately, success depends at least as much on the capacity to execute across legislative and executive branches as on the specie choice of policy" [4, 83-84].

"Companies have a major role to play in delivering higher productivity across sectors through improved and more efficient processes and leveraging technology to the fullest. Governments would need to ensure that the full range of enablers of higher productivity is in place, from competitive intensity to the availability of skills and capital, as well as regulation that promote flexible labour markets that help mitigate the employment impact of change and ensure that companies have the workers they need to thrive. One can now turn to a discussion of ten key enablers that need to be in place to capture the world's full growth potential" $[4,84]$.

Latvia's social infrastructure is one of the essential factors for the country's socio-economic development. Many studies and statistics show the inadequate level of development of social infrastructure in Latvia, and they are one of the factors that determine the level of insufficient level of provocative behaviour. This indicates an inadequate level of government efficiency. For example, the OECD 2015 in the analysis of social infrastructure research, it was found that

- Public education expenditure, benefiting from demographic trends, is projected to decline from $4.4 \%$ of GDP to 3.5\% of GDP by 2050 (European Commission, 2012). Up to the secondary level, Latvia's educational performance, as measured by PISA scores, is slightly above average for the resources committed (Figure 6). [6, 12]

- Latvia is currently performing less well in vocational and higher education. To date, the $\mathrm{VET}^{3}$ has not had a particularly good image; the share of those who consider that VET provides high-quality learning was well below the EU average. $[6,13]$

- The amount of public funding provided for $R \& D$ is the lowest of any EU member state and the lack of public funding is identified by the Ministry of Education as a major factor slowing down scientific progress in the country. Expenditure for scientific research in the business sector in 2010 was $0.22 \%$ of GDP, placing Latvia significantly below the average EU-27 rate of $1.23 \%$ of GDP. $[6,14]$

3 Vocational Education and Training. 
- Public infrastructure is one of the most important public contributors to a favourable business environment and hence to growth potential. Considerable resources are required in this respect. The overall quality of logistical infrastructure in Latvia is perceived as relatively low. $[6,15]$

- Bureaucracy and administrative inefficiency have plagued the Latvian economy. According to the OECD Product Market Regulation (PMR) indicators, businesses face a high degree of red tape, as regulatory procedures seem overly complex, notably in terms of permits and licenses. The administrative burden on start-ups, sole proprietors and corporation is above the OECD average. $[6,26]$

\section{Productivity Comparative Analysis}

The factors that underpin the productivity level and its dynamics are reflected in the WEF GCI Indicator System in a sufficiently detailed manner. As these indicators are comparable across EU countries, the following analysis uses comparative data for $\mathrm{GCI}$ and productivity level.

The authors are aware that the productivity level is the result of the interaction of all the $\mathrm{GCI}$ indicators, and without a deeper study, it is not possible to determine the impact of each factor on the level of productivity and its dynamics by treating massive amounts of data. This analysis is considered as the first step in determining the overall possible relationship between productivity level and $\mathrm{GCI}$ indicators.

At the same time, the profile of individual pillars of the Latvian GCI is given in comparison with some developed countries and groups of countries. Part of the comparisons is given in the EU-28, part of Latvia and EU-15. The use of the EU-15 format is useful for simplifying the images and because the author's interest is related to raising the productivity level to the E-15 level.

GCI and productivity correlations clearly show that countries with a high competitiveness index have a high level of productivity at the same time. In addition, productivity in the EU-15 with a low competitiveness index (Greece, Italy, Spain, Cyprus, Portugal, and Malta) lags behind the most economically strongest in the EU. 
Figure 4. GCI and productivity in the EU-28, 2016

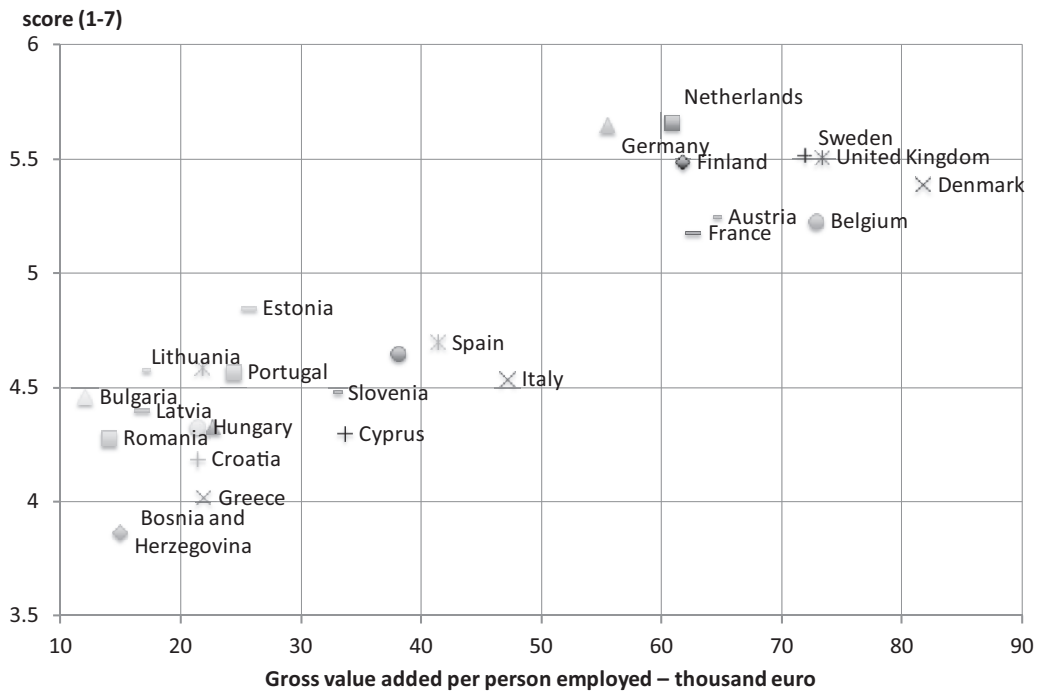

Source: Eurostat database, The Global Competitiveness Report 2017-2018, Author's calculations

On the other hand, in these countries, GCI does not differ much from the new EU member states, which indicates other factors that have a significant impact on productivity, which in turn leads to the assumption that only focusing on improving $\mathrm{GCl}$ indicators may not be enough to increase the competitiveness of the national economy and socio-economic development.

The analysis of the aggregate value of GCl's individual pillars shows that Latvia in most of them is not below the EU average, while macroeconomic stability shows a better result than the EU average. In the author's view, it is wrong to focus on the EU average when it comes to development. With each expansion wave, it is relatively low. Assessing the value of the indicators at the best of the EU, there is already a considerable number of indicators lagging behind (Business sophistication, Institutions, Innovation and Market size). If the size of the internal Market size is relatively independent ${ }^{4}$, then the quality of the institutions is complete, but innovation is to a large extent in the government's field of responsibility.

4 The size of the internal market is determined by the number of inhabitants and their purchasing power. Both of these factors are not only the effects of demographics and market forces, they are also the result of the management process and hence the functioning of state power. 
Figure 5. GCI pillars score in Latvia as a percentage of the maximum and the average of the EU 28, 2016

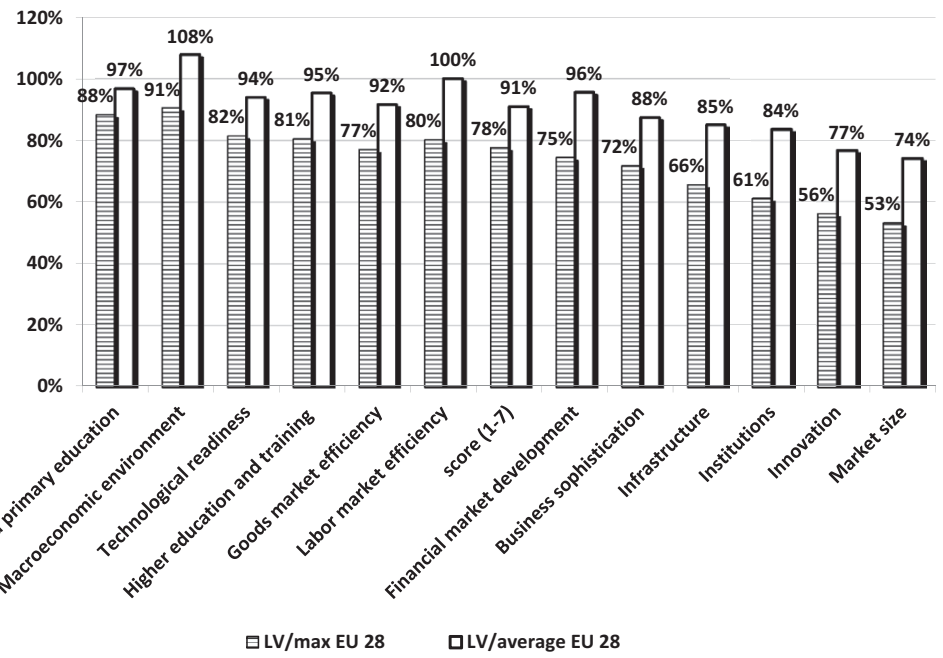

Source: The Global Competitiveness Report 2017-2018, Author's calculations

Productivity comes primarily from the business sector. The Business Sophistication pillar is published by the GCI. Analysis of this pillar and productivity level correlation can serve as the basis for the beginning of a more in-depth study. Figure 6 shows a clear correlation between Business sophistication and productivity. Consequently, the development of the individual factors of this pillar could play a significant role in raising the level of productivity in the Latvian economy. In addition, it should be taken into account that, based on the theory of systems, the group of companies is the control object in the national economic system. Therefore, in order to increase the efficiency of the operation of the system, it is necessary to perform correction management system functions. Assuming that the management of each individual enterprise is carried out by its management, it follows from system theory that the formulation of the objectives of any open system is influenced by metasystem signals. From here, the role of the state lies in the reduction of business efficiency (including productivity level). From the GCl pillar, Business sophistication, Latvia lags far behind "11.03 State of cluster development" and "11.05 Value chain breadth". Taking into account the small size of Latvia, these factors play an important role in boosting business efficiency. 
Figure 6. The link between productivity and GCI (Business Sophistication) in EU countries. 2016

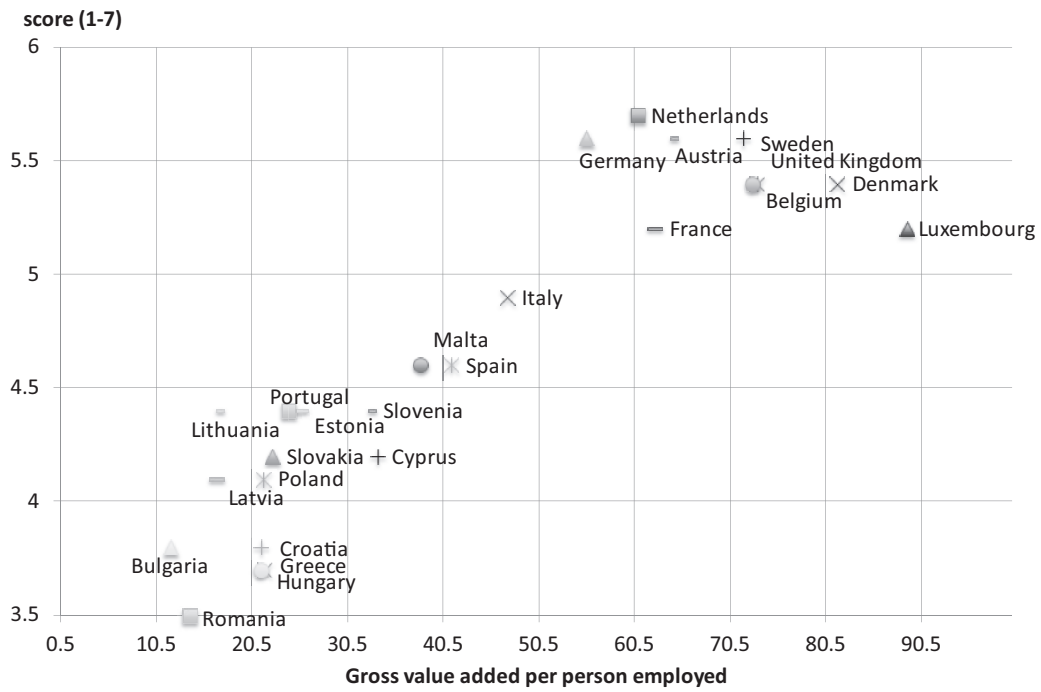

Source: Eurostat database, The Global Competitiveness Report 2017-2018, Author's calculations

Figure 7. Profile of business sophistication Latvia and ES-15, 2016



Source: The Global Competitiveness Report 2017-2018, Author's calculations 
Company internal factor management is the prerogative of corporate boards. Exactly from enterprise, management depends productivity indicators at company level. Unfortunately, "Efficacy of corporate boards" in Latvia, as compared to developed countries, is at a low level

Figure 8. Efficiency of corporate boards Latvia and ES-15, 2016

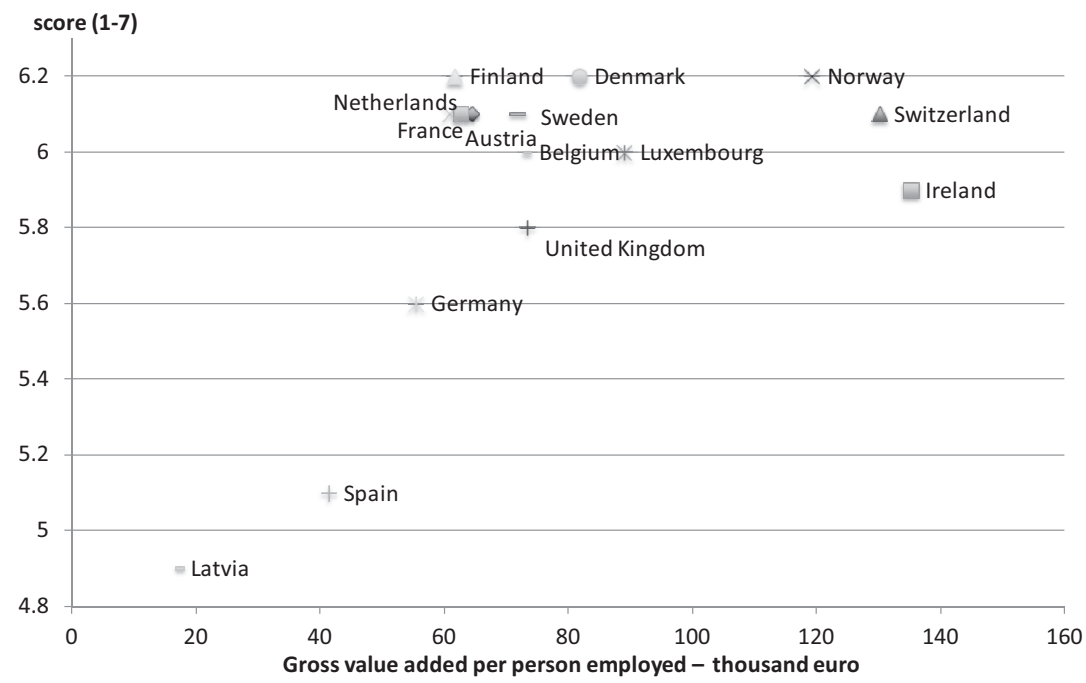

Source: Eurostat database, The Global Competitiveness Report 2017-2018, Author's calculations

Taking into account the role of the state in the country's socioeconomic development, it is interesting to assess the level of productivity at the values of various institutional pillars in individual countries.

The indicator for institutional development owes a similar picture to the overall assessment of $\mathrm{GCI}$ and productivity. At the same time, this leads to the conclusion that the $\mathrm{GCI}$ indicators do not exhaust the government's impact on productivity. These pillars figures, given their supernatural nature, and supposedly according to their authors' neoliberal views on economic development factors, do not include the impact of economic legislation and policies. This can be verified even by observing that Estonia exceeds that figure not only Greece, Spain and Italy, but also France and is on an equal footing with Belgium. 
Figure 9. Link between productivity and GCI (Institutions) in EU countries, 2016

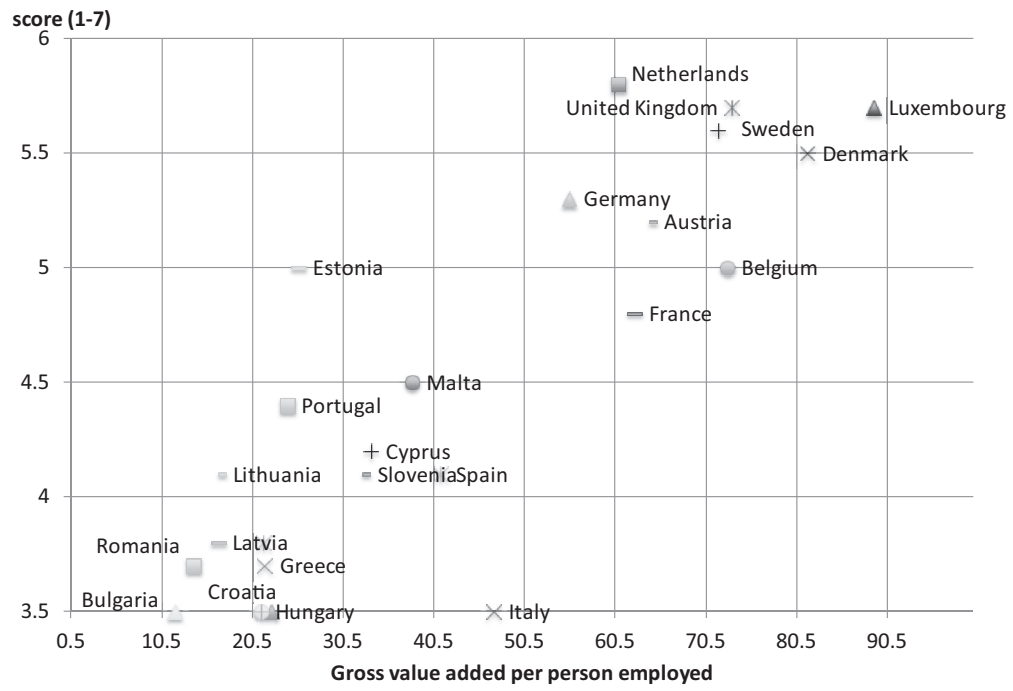

Source: Eurostat database, The Global Competitiveness Report 2017-2018, Author's calculations

Figure 10. Latvian GCI Institutional Pillar Comparative Profile, 2016

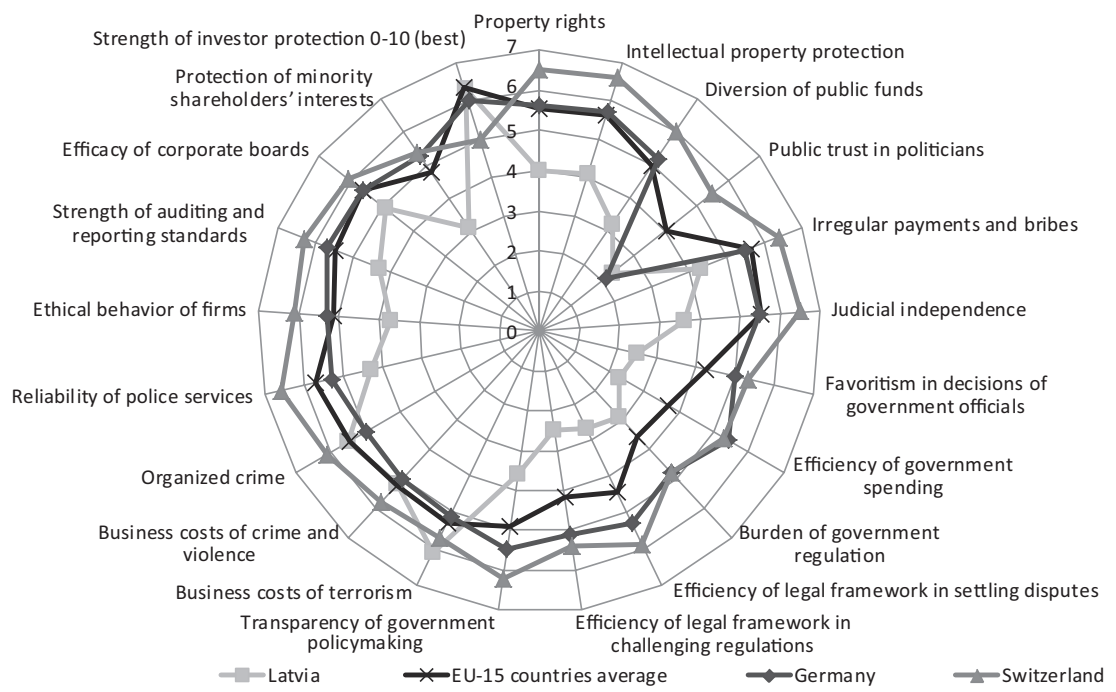

Source: The Global Competitiveness Report 2017-2018, Author's calculations 
Taking into account that the state with legislative force, budgeting and distribution of financial resources, as well as administrative power are influenced by economic entities and their results, the state influence on the productivity level is not only in the institutional sector. Undoubtedly, the effectiveness of a business in a country is influenced by certain factors whose characteristics are included in other pillars $\left(7^{\text {th }}\right.$ pillar: Labour market efficiency, $9^{\text {th }}$ pillar: Technological readiness, $11^{\text {th }}$ pillar: Business sophistication, $12^{\text {th }}$ pillar: Innovation).

Figure 11. Comparative profile of government responsibility factors

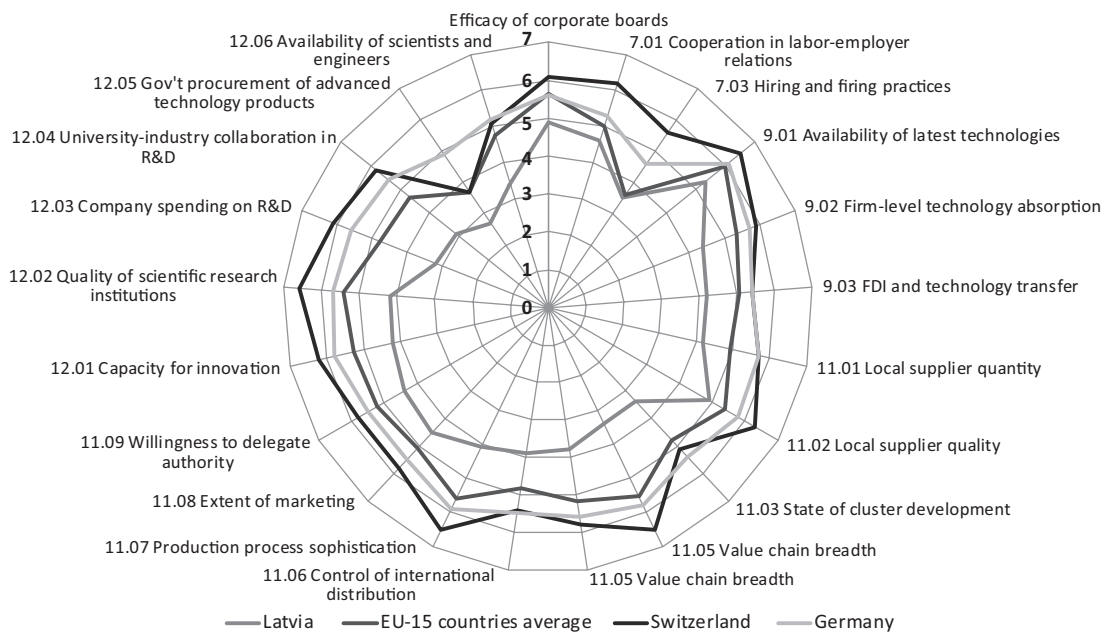

Source: The Global Competitiveness Report 2017-2018, Author's calculations

This extended analysis shows that the $12^{\text {th }}$ pillar is particularly disadvantaged: Innovation, 12.04 University-industry collaboration in $\mathrm{R} \& \mathrm{D}, 7.05$ Effect of taxation on incentives to work, 12.03 Company spending on R \& D, 11.03 State of cluster development, 11.05 Value chain breadth indicators. It is incorrect to assume that these lines of action are the sole responsibility of the business community. The government needs to intervene in the economy if entrepreneurs do not. The government needs to have sufficiently powerful analytical and scientific research capacity to allow monitoring the situation, making decisions and making the necessary changes in economic policy. Mostly the government has direct competence $2^{\text {nd }}$ pillar: Infrastructure.

The state of infrastructure in Latvia, when analysing the WEF GCI indicators, is in a very poor condition. The lower overall infrastructure indicator is only Slovakia, Romania, and Bulgaria. Infrastructure development 
policy, infrastructure development and maintenance are based on government competence. Exactly infrastructure development is probably one of the most important directions for increasing productivity.

Figure 12. Labour productivity and GCI (Infrastructure) aggregation in EU countries, 2016

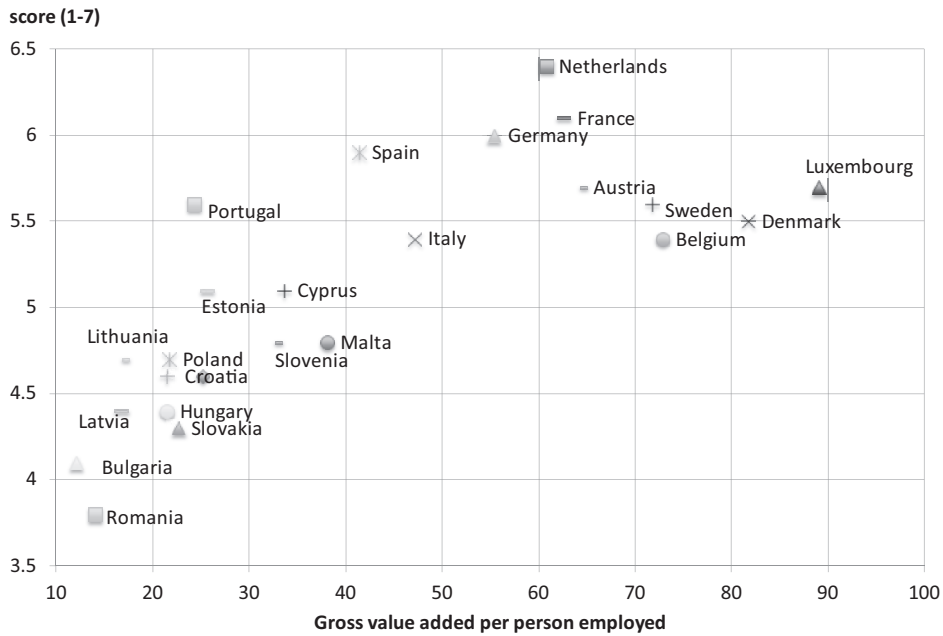

Source: Eurostat database, The Global Competitiveness Report 2017-2018, Author's calculations

Figure 13. Labour productivity and GCI (Higher education and training) aggregation in the EU countries, 2016

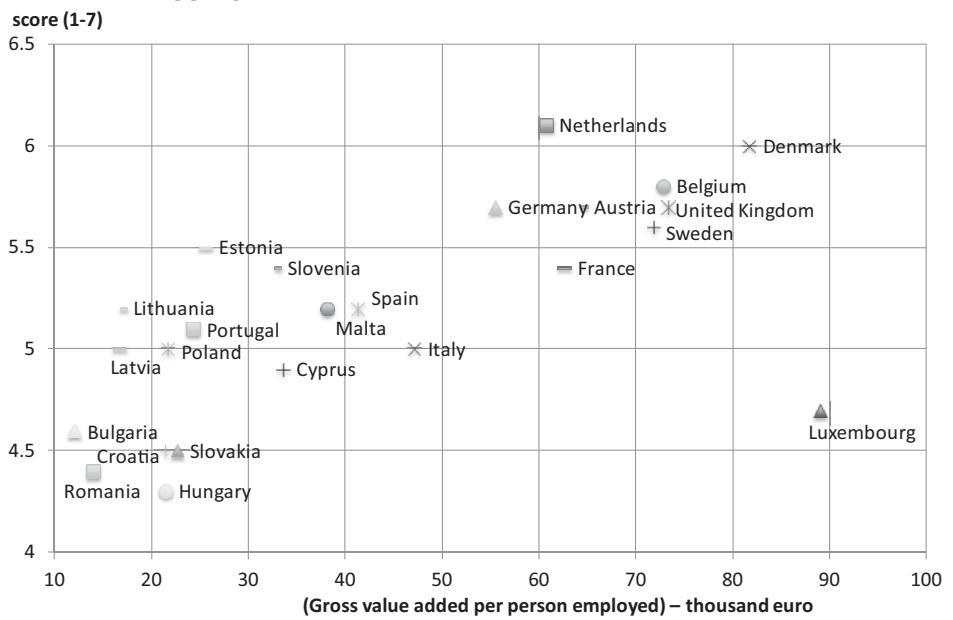

Source: Eurostat database, The Global Competitiveness Report 2017-2018, Author's calculations 
The GCI pillar of Higher Education and Training, with a productivity level, shows similar results as other $\mathrm{GCI}$ indicators. Taking into account studies on the level of development of higher education in the country, this factor group is also a significant factor in increasing productivity. More so because of the fact that the education sector directly affects the $1^{\text {st }}$ pillar: Institutions $12^{\text {th }}$ pillar: Innovation $11^{\text {th }}$ pillar: Business sophistication.

Figure 14. Productivity and national size (population) I, 2016

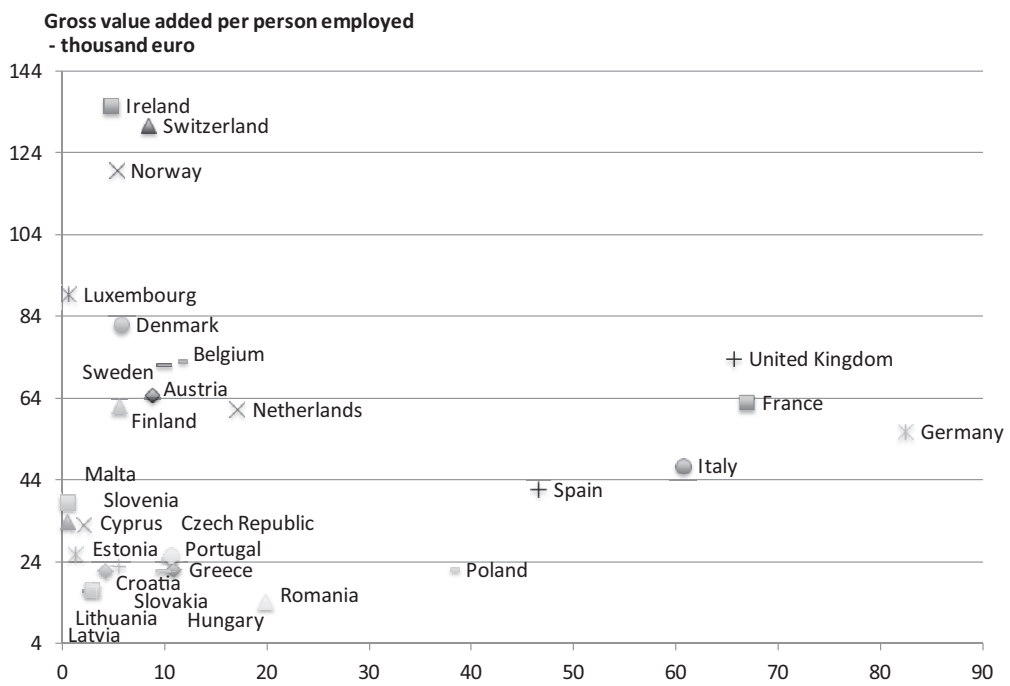

Source: Eurostat database, The Global Competitiveness Report 2017-2018, Author's calculations

One of the indicators that distinguishes Latvia from most of the EU countries is its size (population). One of the hypotheses put forward is that Latvia, as a small country, has a serious constraint on economic development in the existing technological formation. Therefore, it is worthwhile to compare the level of productivity with the size of the state. 
Figure 15. Productivity and national dimensions (population) II, 2016

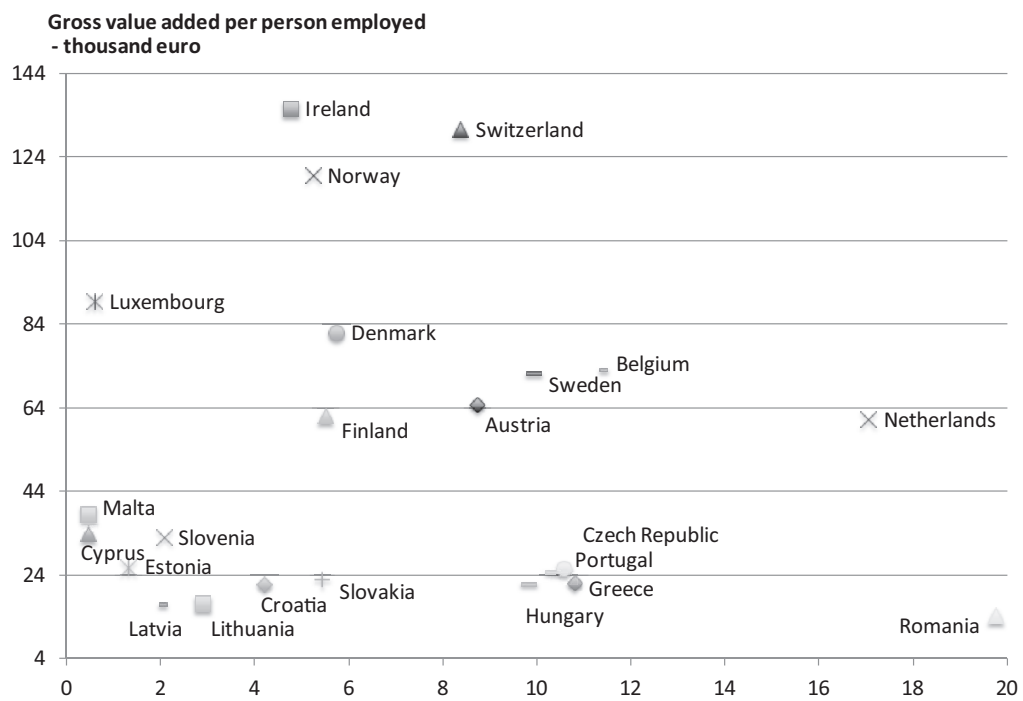

Source: Eurostat database, The Global Competitiveness Report 2017-2018, Author's calculations

Comparison of national size and productivity level does not give enough confirmation or denial of this hypothesis. This requires in-depth research.

\section{Conclusions}

Productivity is one of the key factors contributing to economic growth. It affects economic growth, reducing production costs and effectively using production factors.

The analysis of the aggregate value of GCl's individual pillars shows that Latvia in most of them is not below the EU average, while macroeconomic stability shows a better result than the EU average.

Productivity comes primarily from the business sector. Unfortunately, "Efficacy of corporate boards" in Latvia, as compared to developed countries, is at a low level. From the GCI pillar, Business sophistication, Latvia lags far behind "11.03 State of cluster development" and "11.05 Value chain breadth". Taking into account the small size of Latvia, these factors play an important role in boosting business efficiency.

The results of the study indicate that productivity is higher in those EU countries with strong institutional development, economic, educational and health infrastructures and are involved in technological innovation. 
The indicator for institutional development owes a similar picture to the overall assessment of GCI and productivity. At the same time, this leads to the conclusion that the $\mathrm{GCI}$ indicators do not exhaust the government's impact on productivity. These pillars do not include the impact of economic legislation and policies.

The state of infrastructure in Latvia, when analysing the WEF GCI indicators, is in a very poor condition. Infrastructure development policy, infrastructure development and maintenance are based on government competence.

Taking into account that the state with legislative force, budgeting and distribution of financial resources, as well as administrative power are influenced by economic entities and their results, the state influence on the productivity level is not only in the institutional sector. Undoubtedly, the effectiveness of a business in a country is influenced by certain factors whose characteristics are included in other pillars $\left(7^{\text {th }}\right.$ pillar: Labour market efficiency, $9^{\text {th }}$ pillar: Technological readiness, $11^{\text {th }}$ pillar: Business sophistication, $12^{\text {th }}$ pillar: Innovation).

Analysis shows that the $12^{\text {th }}$ pillar is particularly disadvantaged: Innovation, 12.04 University-industry collaboration in R \& D, 7.05 Effect of taxation on incentives to work, 12.03 Company spending on R \& D, 11.03 State of cluster development, 11.05 Value chain breadth indicators.

The GCI pillar of Higher Education and Training, with a productivity level, shows similar results as other $\mathrm{GCI}$ indicators. The education sector directly affects the $1^{\text {st }}$ pillar: Institutions $12^{\text {th }}$ pillar: Innovation $11^{\text {th }}$ pillar: Business sophistication.

It is necessary for countries to invest more in research and development activities in order to implement technological development, as well as creating an appropriate environment for cooperation between state institutions and entrepreneurs for increasing productivity.

The government needs to have sufficiently powerful analytical and scientific research capacity to allow monitoring the situation, making decisions and making the necessary changes in economic policy.

\section{REFERENCES}

1. Ai-Ting Goh and Tomasz Michalski. Should small countries fear deindustrialization? Finance and Economics Department, HEC Paris May 19, 2009.

2. Artur Woll. Allgemeine Volkswirtschaftslehre. Verlag Franz Vahlen München. 1987. 626. Seiten.

3. Bräutigam, Deborah; Woolcock, Michael. Working Paper. Small states in a global economy: The role of institutions in managing vulnerability and opportunity in small developing countries. WIDER Discussion Papers // World Institute for Development Economics (UNU-WIDER), No. 2001/37, 16 p. 
4. Can productivity save the day in an aging world? McKinsey Global Institute. January 2015.

5. Glossary: Apparent labour productivity - SBS. http://ec.europa.eu/eurostat/ statistics-explained/index.php/Glossary: Apparent_labour_productivity_-_SBS

6. Improving public sector efficiency for more inclusive growth in Latvia. OECD Economics department working papers No. 1254, By Caroline Klein and Robert Price. 28 p.

7. Jörg König and Renate Ohr Small but Beautiful? Economic Impacts of the Size of Nations in the European Union. Center for European Govenance and Economic Development research. Discussion Papers number 128 - August 2011. p. 20.

8. Latvijas Nacionālais attīstības plāns 2014.-2020. gadam. Apstiprināts ar 2012. gada 20. decembra Latvijas Republikas Saeimas lēmumu. Pārresoru koordinācijas centrs. 2012. gada decembris.

9. Lieberman, M. B., \& Kang, J. (2008). How to Measure Company Productivity Using Value-Added: A Focus on Pohang Steel (POSCO). Asia Pacific Journal of Management, 25(2), 209-224. http://dx.doi.org/10.1007/s10490-007-9081-0.

10. Математика и кибернетика в экономике издательсво Экономика Москва, $1975,681 \mathrm{c}$.

11. Measuring productivity. Measurement of aggregate and industry-level productivity growth. OECD manual. Organization for economic co-operation and development. OECD publications. 2001. p. 154.

12. OECD Glossary of Statistical Terms. OECD 2008 p. 601.

13. Smidova, Z. (2015), "Policy areas for increasing productivity in Latvia economics", OECD Economics Department Working Papers, No. 1255, OECD Publishing, Paris. http://dx.doi.org/10.1787/5jrw57nr0f23-en.10-aug-2015.

14. Syverson, C. (2011). What Determines Productivity? Journal of Economic Literature, 49(2), 326-365. https://doi.org/10.1257/jel.49.2.326.

15. Taylor, T., Greenlaw, S. A., Dodge, E., ... \& Sonenshine, R. (2016). Principles of Economics. US: Rice University, Open Stax.

16. The Global Competitiveness Report 2017-2018 World Economic Forum.

17. The public-sector productivity imperative, McKinsey Public Sector Practice, March 2011, How can American government meet its productivity challenge? McKinsey \& Company, July 2006.

18. Why Do Some Countries Produce So Much More Output Per Worker Than Others? Author(s): Robert E. Hall and Charles I. Jones Source: The Quarterly Journal of Economics, Vol. 114, No. 1 (Feb., 1999), pp. 83-116 Published by: Oxford University Press.

19. World Economic Situation and Prospects 2017. United Nations New York, 2017. p. 191.

20. Yashiro, N. et al. (2017), "Moving up the global value chain in Latvia”, OECD Economics Department Working Papers, No. 1438, OECD Publishing, Paris. 